\begin{tabular}{cc|c}
\hline Tar. Bil. Der. & Tarım Bilimleri Dergisi & Journal of Agricultural Sciences \\
& $\begin{array}{c}\text { Dergi web sayfası: } \\
\text { www.agri.ankara.edu.tr/dergi }\end{array}$ & Journal homepage: \\
& www.agri.ankara.edu.tr/journal
\end{tabular}

\title{
Effect of Cup Size, Seed Characteristics and Angular Speed on the Performance of an Automatic Potato Planter under Laboratory Conditions
}

\author{
Mustafa Gökalp BOYDAŞa \\ a Atatürk Universiy, Faculty of Agriculture, Department of Agricultural Machinery and Technologies Engineering, 25240, Erzurum, \\ TURKEY
}

\section{ARTICLE INFO}

Research Article

DOI: 10.15832 /ankutbd.447634

Corresponding Author: Mustafa Gökalp BOYDAŞ, E-mail: mboydas@atauni.edu.tr, Tel: +90 (442) 2312549

Received: 12 June 2015, Received in Revised Form: 14 December 2015, Accepted: 17 December 2015

\begin{abstract}
The seed metering mechanism is the most important unit of potato planters. Accuracy of row plant spacing depends on the ability of the seed metering mechanism. The ability of the seed metering mechanism is directly associated with the constructive and operational variables of the planter. This study was conducted to evaluate the effects of different cups sizes $(\mathrm{C} 1<\mathrm{C} 2<\mathrm{C} 3$ ), different seed sizes ( 25 to 45 and 45 to $65 \mathrm{~mm}$ ), different shapes (oblong and spherical), and angular speeds $\left(0.9,2.04\right.$ and $\left.3.18 \mathrm{rad} \mathrm{s}^{-1}\right)$ on the seed metering mechanism in a full automatic potato planter. The cup, angular speed, seed size and shape have an important role on the efficiency of the seed metering mechanism. The seed spacing uniformity was determined including doubles and skips. The coefficient of variation (CV\%) was used to determine the seed spacing uniformity. The values of CV\% for cups were $29.24,23.76$ and $26.11 \%$ for C1, C2 and C3, respectively. C3 has the highest percent value of doubles and the lowest percent value of skips. The seed spacing uniformity of oblong potato seeds was better than that of spherical potato seeds. The percent value of doubles increased and percent value of skips decreased for oblong potato seeds, opposite to the spherical potato seeds. The seed size of 45-65 mm gave a better seed spacing uniformity than the other seed size. It was observed that the seed size of $25-45 \mathrm{~mm}$ had higher percent value of doubles. The seed spacing uniformity tended to increase as the angular speed reduced. The CV\% values of angular speed were $22.83,24.90$ and $31.39 \%$ for $0.9,2.04,3.18 \mathrm{rad} \mathrm{s}^{-1}$, respectively. As the angular speed increased, percent value of doubles decreased and percent value of skips increased.
\end{abstract}

Keywords: Seed metering mechanism; Seed spacing uniformity; Laser measurement system; Doubles; Skips

\section{Laboratuvar Koşullarında Otomatik Bir Patates Dikim Makinasının Performansına Kepçe Büyüklüğünün, Tohum Karakteristiklerinin ve Açısal Hızın Etkisi}

\author{
ESER BİLGISİ \\ Araştırma Makalesi \\ Sorumlu Yazar: Mustafa Gökalp BOYDAŞ, E-posta: mboydas@atauni.edu.tr, Tel: +90 (442) 2312549 \\ Geliş Tarihi: 12 Haziran 2015, Düzeltmelerin Gelişi: 14 Aralık 2015, Kabul: 17 Aralık 2015
}




\section{ÖZET}

Tohum dağıtma düzeni patates dikim makinalarının en temel kısmını oluşturmaktadır. Sıra üzeri tohum dağılım düzgünlüğündeki doğruluk, tohum dağıtma düzeninin kabiliyetine bağlıdır. Tohum dağıtma düzeninin bu kabiliyeti yapısal ve çalışma şartlarına direkt olarak bağlıdır. Bu çalışma, tam otomatik bir patates dikim makinasında farklı büyüklükte kepçelerin $(\mathrm{C} 1<\mathrm{C} 2<\mathrm{C} 3)$, farklı büyüklükteki tohumların (25 ile $45 \mathrm{~mm}$ ve 45 ile $65 \mathrm{~mm}$ arası), farklı şekildeki tohumların (uzun ve küresel) ve farklı açısal hızların $\left(0.9,2.04\right.$ ve $\left.3.18 \mathrm{rad} \mathrm{s}^{-1}\right)$ tohum dağıtma düzeni üzerine etkisini belirlemek için yürütülmüştür. Kepçelerin, açısal hızın, tohum büyüklügünün ve şeklinin tohum dağıtma düzeni üzerine önemli bir etkiye sahip olduğu görülmüştür. Denemede, tohum dağılım düzgünlüğ̈̈, ikili atma ve boş bırakma belirlenmiştir. Tohum dağılım düzgünlügünü belirlemede varyasyon katsayısı (\% CV) kullanılmıştır. C1, C2 ve C3 kepçeleri için en büyük \% CV değerleri sirayla \% 29.24, 23.76 ve 26.11 olarak bulunmuştur. C3 kepçesiyle en büyük ikili atma ve en küçük boş birakma değerleri elde edilmiştir. Uzun tohumlardan elde edilen tohum dağılım düzgünlüğünün küresel tohumlara göre daha iyi olduğu belirlenmiştir. Uzun tohumlarda ikili atmanın arttığı ve boş bırakmanın azaldığg görülmüştür. Küresel tohumlarda ise bunun tam aksi görülmüştür. 45-65 mm aralığındaki tohumlardan elde edilen \% CV değerlerinin 25-45 mm aralığındaki tohumlardan elde edilen \% CV değerinden daha düşük olduğu belirlenmiştir. 25-45 mm aralığındaki tohumların ikili atmayı artırdığı görülmüştür. Açısal hızdaki azalma tohum dağılım düzgünlüğünde iyileşmeye neden olmuştur. Farklı açısal hızlardan elde edilen \% CV değerleri; 0.9, 2.04, $3.18 \mathrm{rad} \mathrm{s}^{-1}$ için sirasıyla \% 22.83, 24.90 ve 31.39 olarak bulunmuştur. Açısal hızdaki artış ikili atmada azalışa ve boş bırakmada artışa neden olmuştur.

Anahtar Kelimeler: Tohum dağıtma düzeni; Tohum dağılım düzgünlüğü; Lazer ölçüm sistemi; İkizlenme; Boş bırakma

(C) Ankara Üniversitesi Ziraat Fakültesi

\section{Introduction}

Potato is an important food crop for humans and animals due to its desirable starch, protein and vitamins contents. The potato is used as a versatile vegetable and in the industry. The potato is grown in many countries around the world and in different climates (Taheri \& Shamabadi 2013; Potato 2015). The potato acreage in Turkey is 125030 ha resulting in a harvest of 3.9 million tonnes of tubers and yield is 31.6 tons per ha for the year 2013 (FAO 2015). The most common potato varieties in Turkey have yellow flesh are Marabel, Marfona, Granola, Latona, Adora, Atlas, Fabula, Lady Rosetta, Lady Claire, Russet Burbank, Shepody, Agria and Van Gogh. According to regional conditions in Turkey, traditional and modern methods are used in the potato production. Traditional potato production is difficult, time consuming and labor intensive. Therefore, most of the farming operation for this crop has been mechanized to reduce the cost of production. There are three main stages in potato production: planting, cultivating, and harvesting. Planting has an important effect on the potato yield. Planting is performed by hand, semi-automatic planters, and fully automatic planters. Planting done by hand is time-consuming and requires a great deal of labor. Semi-automatic potato planters have a suitable performance and low labor and less time-consuming compared to planting by hand. Labor and time-consuming in fully automatic potato planters are the lowest level. Results achieved in potato planting by machine depend on complex relationships between the technical quality of machine performance and the ability to work fast with a minimum demand for labour (Culpin 1992; Steele et al 2010). The fully automatic potato planters release potato seeds in furrows at desired certain spacing and depth. A potato planting machine has many different parts such as frame, wheels, seed metering mechanism, furrow openers, covering discs, and the seed spacing adjustment gear. Among these parts, the seed metering mechanism is a crucial one. Accuracy of in-row seed spacing is the main parameter of the seed metering mechanism. Because, improvement of plant spacing uniformity leads to high yield, and to facilitate harvesting and post-harvest operations (McPhee et al 1996; Pavek \& Thornton 2003). The plant uniformity affects development, yield and seed quality of plant (Bussan et al 2007; Güllüoglu \& Arioglu 2009). Seed spacing uniformity has very important role for evaluating a 
potato planter performance (Zoraki \& Acar 2000; Seyedbagheri 2006). To increase yield and quality of potato, uniform seed spacing is required (Klassen 1974; Klassen 1975). Rupp \& Thornton (1992) found that a $10 \%$ decrease or increase in the optimum plant number leads to reduce yield from $2 \%$ to $12 \%$. Furthermore, they said that increasing skips and doubles reduced economic return compared with uniform seed spacing. Deep planting and diseased seed can cause skips to increase (Cross \& Ohms 1967; James at al 1973). However, James et al (1975) determined that $88 \%$ of skips were due to the lack of seed. Some researchers found that the skips were mainly caused by mechanical deficiencies of the potato planter (Misener 1979). James et al (1973) found that 10, 20 and $30 \%$ of skips led to $0,5.6$ and $11.1 \%$ average yield loss, respectively. However, potato yield is a good criterion along with the market value of tubers in the proto production. Therefore, the physical properties of potato tubers also have an important role in appearance at markets. Tuber size is more important indication of marketable yield than the total tuber yield. Some researchers have showed that seed spacing uniformity plays a major impact on marketable yield (Schotzko et al 1983; Thornton et al 1983; Rex et al 1987; Rupp \& Thornton 1992; Creamer et al 1999; Love \& Thompson-Johns 1999). Getachew et al (2012) determined the effect of seed spacing on total yield and marketable yield of potato in Ethiopia. They found the highest total tuber yield at seed spacing of $10 \mathrm{~cm}$ whereas marketable tuber yield at seed spacing of $10 \mathrm{~cm}$ had the lowest value. Similarly, Love \& Thompson-Johns (1999) determined that seed planted at seed spacing of 8 $\mathrm{cm}$ resulted in more potato yields than those of seed planted at spacing from 15 to $91 \mathrm{~cm}$. But, they said that the market value decreased due to increasing percent of small potatoes. Naturally, accuracy of seed spacing changes depending on the size and shape of cups. However, although many works were done on potato planters, studies on the effect of cups on seed spacing uniformity are limited. Buitenwerf et al (2006) studied on cup-belt planter and stated that the geometry of cups should be focused. In addition, previous research (Khairy 1997; Altuntas 2005; AlGaadi \& Marey 2011) showed that there was an effect of ground speed, and different seed sizes and shapes on seed spacing uniformity. Altuntas (2005) reported that in-row spacing uniformity decreased as ground speed increased. Khairy (1997) found that when the ground speed was higher than $3.6 \mathrm{~km} \mathrm{~h}^{-1}$, seed spacing uniformity became worse. Similarly, Al-Gaadi \& Marey (2011) determined that the lowest and the highest mean values of CV\% were 28.73 and $54.53 \%$ for ground speed of 1.80 and $3 \mathrm{~km} \mathrm{~h}^{-1}$, respectively. Sieczka et al (1986) stated that high planting speeds reduced performance of potato planter. Buitenwerf et al (2006) determined that potato shape had an important effect on seed spacing uniformity.

The objective of this study was to determine the effect of three various size cups, three different angular speeds, and two several seed size and shape on the seed spacing uniformity, skips and doubles; and then to develop a measurement system suitable for laboratory and field studies.

\section{Material and Methods}

\subsection{Potato planter, cups, and angular speeds}

The experiments were conducted at the laboratory of Agricultural Farm Machinery Department, Ataturk University, Erzurum, Turkey. The laboratory temperature and relative humidity were measured as $9{ }^{\circ} \mathrm{C}$ and $25 \%$, respectively. A full automatic potato planter (Model: YN-08 Kenan Ertugrul, Nevsehir, Turkey) (Figure 1) was used in the experiments.

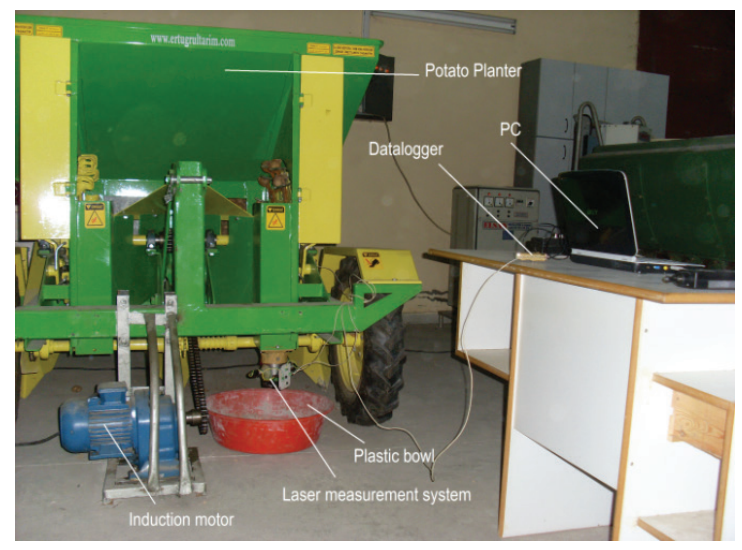

Figure 1- Potato planter and test rig

Şekil 1- Patates dikim makinası ve deney düzeneği 
The potato planter consists of two rows. The seed metering mechanisms are placed under the hopper, and driven by ground wheels. The seed metering mechanism consists of a vertical disc, cups, holding pins, and torsion springs. The 14 cups, 14 holding pins, and 14 torsion springs are attached with equal angles to the vertical disc.

The seed metering mechanism works like a water mill. The cups, attached to vertical disc, clutch potato seeds in the bottom of seed hopper while the vertical disc rotates. Then, seed entering into the cup is kept by the holding pin, and transferred out of the seed hopper. After vertical disc revolves $190^{\circ}$, the holding pin is opened by the pin-position cam. So, potato seed drops into furrow (Figure 4). The force exerted by helical spring was $11.96 \pm 0.96 \mathrm{~N}$. The cups with three different sizes (Figure 2) (small, middle and big is $\mathrm{C} 1, \mathrm{C} 2$ and $\mathrm{C} 3$, respectively) were used in the experiment. All cups were made of cast iron. The dimensions of these cups are presented in Table 1 and Figure 3. Three angular speeds for the seed metering mechanism were determined by taking into account the maximum and minimum forward speeds and seed rates of the potato planter, because while the ground speed and seed rates change, the angular speeds of the seed metering mechanism change. So, the angular speeds of the seed metering mechanism were selected as $0.9,2.04$ and $3.18 \mathrm{rad} \mathrm{s}^{-1}$. The seed rates were 120, 273 and 425 seed min $^{-1}$ for these angular speeds, respectively. These angular speeds were provided by an $\mathrm{AC}$ three phase inverter which changed the rpm of the three-phase electric motor attached by a roller chain to the axle of the vertical disc.

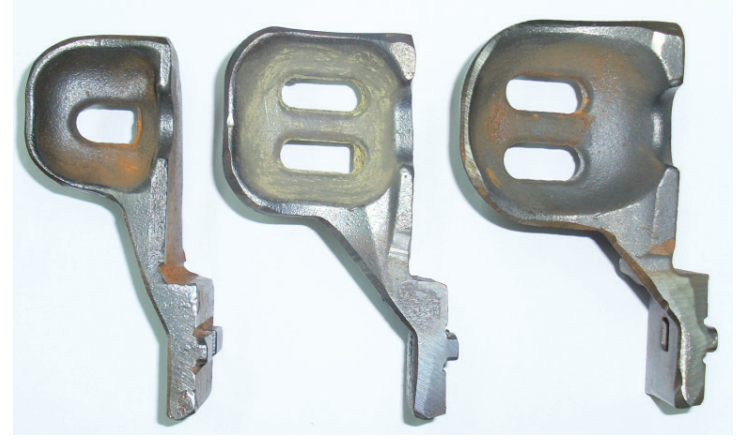

Figure 2- Cups used in the experiment

Şekil 2- Denemede kullanılan kepçeler
Table 1- Selected dimensions of the cups

Çizelge 1- Kepçelerin seçilmiş boyutları

\begin{tabular}{lccccc}
\hline Cups & $A, \mathrm{~mm}$ & $\mathrm{~B}, \mathrm{~mm}$ & $\mathrm{C}, \mathrm{mm}$ & $\mathrm{D}, \mathrm{mm}$ & $\mathrm{E}, \mathrm{mm}$ \\
\hline $\mathrm{C} 1$ & 50 & 40 & 50 & 45 & 15 \\
C2 & 64 & 54 & 64 & 54 & 21 \\
C3 & 76 & 65 & 76 & 65 & 25 \\
\hline
\end{tabular}
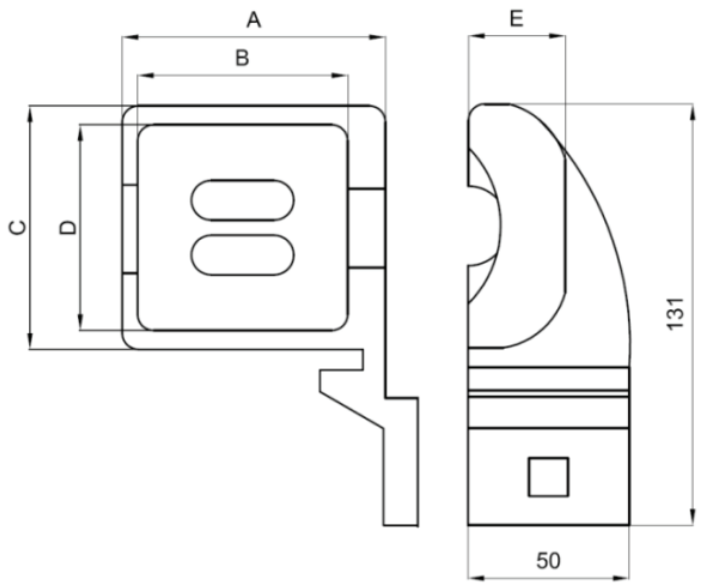

Figure 3- Dimensions of the cups

Şekil 3- Kepçelerin boyutları

\subsection{Seed material}

Agria and Marfona cultivars were used as seed materials in the experiments. These cultivars had different shapes from each other. Until the experiments were conducted, the potato seeds were stored in a warehouse under appropriate conditions. The potato seeds were separated into two groups. The first group was between $25-45 \mathrm{~mm}$ seed size, and the second group was between 45-65 mm seed size. Some physical properties of seeds were presented in Table 2.

Shape factor $(S f)$ was determined with Equation 1 (Buitenwerf et al 2006).

$S_{f}=\frac{a^{2}}{b c} \times 100 \%$

Where; $a, b$ and $c$, length, width and height of the seed as mm, respectively. The $a, b$ and $c$ dimensions have a relationship of $\mathrm{c}<\mathrm{b}<\mathrm{a}$ (Mohsenin 1986). 
Table 2- Some physical properties of Marfona and Agria*

Çizelge 2-Marfona ve Agria'nın bazı fiziksel özellikleri*

\begin{tabular}{lrrrr}
\hline & \multicolumn{2}{c}{ Agria } & \multicolumn{2}{c}{ Marfona } \\
\cline { 2 - 5 } & \multicolumn{1}{c}{$45-45 \mathrm{~mm}$} & $45-65 \mathrm{~mm}$ & $25-45 \mathrm{~mm}$ & $45-65 \mathrm{~mm}$ \\
\hline $\mathrm{a}, \mathrm{mm}$ & $60.97 \pm 4.02$ & $70.88 \pm 3.53$ & $50.18 \pm 3.43$ & $56.94 \pm 5.68$ \\
$\mathrm{~b}, \mathrm{~mm}$ & $43.10 \pm 1.56$ & $49.42 \pm 3.42$ & $43.89 \pm 3.51$ & $51.65 \pm 2.61$ \\
$\mathrm{c}, \mathrm{mm}$ & $36.07 \pm 2.58$ & $41.54 \pm 2.93$ & $41.57 \pm 2.52$ & $44.41 \pm 2.06$ \\
$\mathrm{D}_{\mathrm{p}}, \mathrm{mm}$ & $45.54 \pm 1.39$ & $52.55 \pm 2.35$ & $45.02 \pm 2.28$ & $50.69 \pm 2.61$ \\
Mass, g & $54.53 \pm 3.40$ & $83.58 \pm 12.29$ & $53.43 \pm 4.94$ & $74.91 \pm 11.16$ \\
Shape factor & $242.33 \pm 44.57$ & $246.70 \pm 27.65$ & $138.92 \pm 16.80$ & $142.08 \pm 23.30$ \\
Percent sphericity & $75 \pm 4.00$ & $74 \pm 3.00$ & $90 \pm 3.00$ & $89 \pm 5.00$ \\
\hline
\end{tabular}

*, values are presented as mean \pm standard deviation; $a, b$ and $c$, dimensions of the principle axes; $D_{p}$, geometric mean diameter

Sphericity $\left(S_{p}\right)$ and geometric mean diameter $\left(D_{p}\right)$ were determined by Equation 2 and 3 (Mohsenin 1986).

$$
\begin{aligned}
& S_{p}=\frac{(a b c)^{1 / 3}}{a} \times 100 \% \\
& D_{p=(a b c)^{1 / 3}}
\end{aligned}
$$

\subsection{Measurement system}

The measuring system was composed of two main parts: 1) Laser measuring unit used to determine the seed spacing uniformity, doubles, and skips, and 2) angular speed measuring unit (Figure 4).

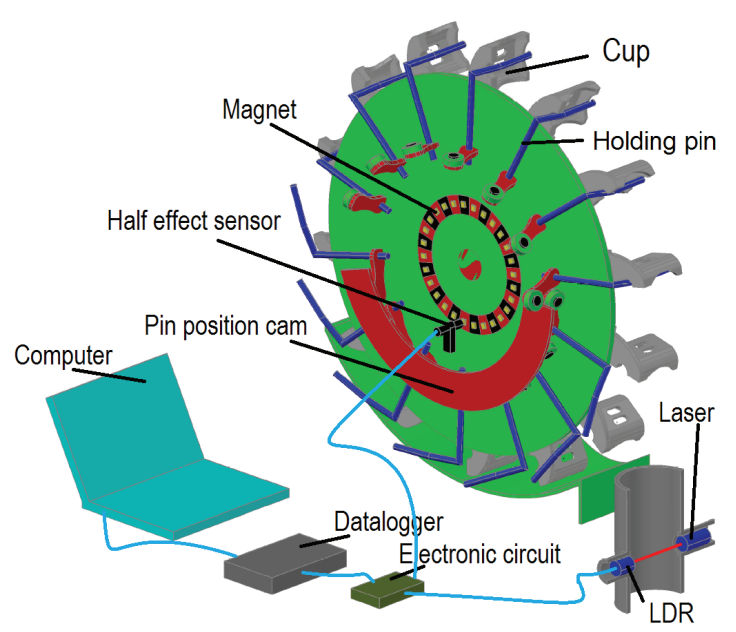

Figure 4- Measurement system

Şekil 4- Ölçüm sistemi
The laser measurement unit consists of a light dependent resistor (LDR), a laser pointer, a pipe of $80 \mathrm{~mm}$ diameter, and an electronic circuit. The laser measurement unit was attached under the cups. The unit measures time intervals between seeds falling down from cups (Boydas \& Uygan 2012). Seeds passed through the pipe create a signal, and this signal is sent to the electronic circuit, then to the digital port of datalogger. So, a square wave is obtained from the unit. The time interval between two peaks of a square wave is used to determine seed spacing uniformity, percent value of skips, and percent value of doubles (Figure 5).

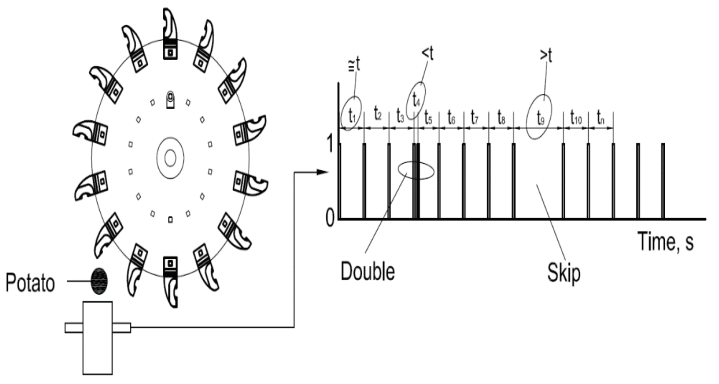

Figure 5- The square wave obtained from falling seeds

Şekil 5-Düşen tohumlardan elde edilen kare dalga

Angular speed measuring unit consists of a half effect sensor, neodymium magnets, and an electronic circuit. The magnets were positioned in the circumference of the vertical disc. The 
half effect sensor was placed exactly in front of the magnets (Figure 6). While the vertical disc rotated, a square wave was obtained from the half effect sensor. This signal was sent to the electronic circuit (Figure 7). The rpm of the seed metering mechanism and two threshold values giving doubles and skips were determined with the help of the half effect sensor. The time between two square waves was shown with " $t$ " (Figure 7). The value of $t$ changed depending on the change in angular velocity of the seed metering mechanism. The value of $t$ was calculated with a program written in MATLAB.

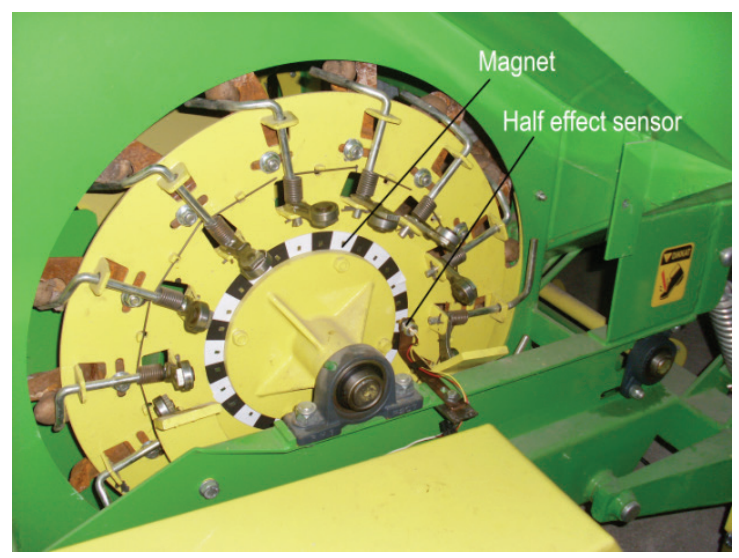

Figure 6- Half effect sensor, and magnets ranked the circumference of the seed metering mechanism

Şekil 6- Half effect sensor ve tohum dağıtma düzeni etrafina dizili mıknatıslar

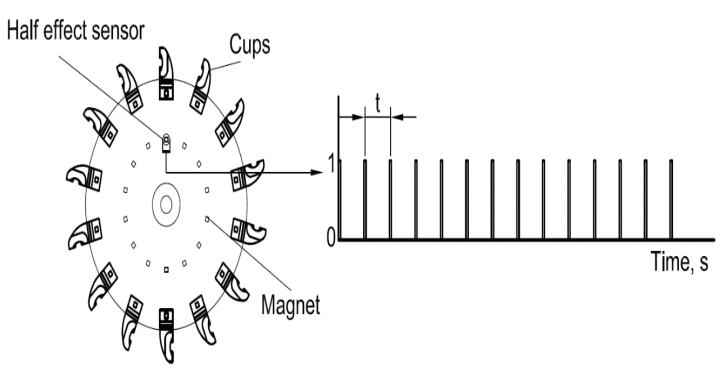

Figure 7- The square wave obtained from half effect sensor

Şekil 7- Hallf effect sensörden elde edilen kare dalga
Time intervals obtained from the laser measurement system and time intervals obtained from the half effect sensor should be equal, theoretically. However, it is not possible in practice, and time intervals obtained from the laser measurement system change due to skips, doubles and irregular drops (Figure 5). To find the percent value of doubles and skips, two threshold values, named as $t_{d}$ and $t_{s}$, were used. The $t_{d}$ and $\mathrm{t}_{\mathrm{s}}$ were determined by using the Equation 4 and 5 .

$t_{d} \leq \mathrm{t} \times 0.7$

$t_{s} \geq \mathrm{t} \times 1.5$

If the time interval obtained from the laser measurement system is less than the $t_{d}$, there is doubles. If the time interval obtained from the laser measurement system is higher than the $t_{s}$, there is skips. Therefore, the values of 0.7 and 1.5 were chosen for safety. For example, the time interval obtained from the half effect sensor is $5 \mathrm{~s}(\mathrm{t}=5 \mathrm{~s})$, the time intervals obtained from the laser measurement system are $7,12,3,17,8$, and $2 \mathrm{~s}$, respectively. To find skips and doubles, these values were divided by the $\mathrm{t}$ value. It gets $7 / 5=1.4,12 / 5=2.4,3 / 5=0.6,17 / 5=3.4$, $8 / 5=1.6$, and $2 / 5=0.4$. The value of 1.4 is between 0.7 and 1.5 , then there are no skips and doubles in this time interval. When we consider the value of 2.4 , we see the two skips. For the value of 0.6 is smaller than 0.7 , there is one doubles (Equation 6).

Percent value of doubles $=\frac{N_{d} 100}{N}$

Where; $N_{d}$, total number of doubles and $N$, total number of time intervals obtained from half effect sensor (Equation 7).

$$
\text { Percent value of skips }=\frac{N_{s .} 100}{N}
$$

Where; $N_{s}$, total number of skips.

The $t_{d}, t_{s}, N_{d}$, and $N_{s}$ values were determined with the aid of a program written in MATLAB (Mathworks 2011).

To determine coefficient of variation of seed spacing or irregularity in the time interval, coefficient 
of variation $(\mathrm{CV} \%)$ was used, and calculated as shown in Equation 8.

$$
\mathrm{CV} \%=\frac{S D .100}{X_{m}}
$$

Where; $S D$, standard deviation of time intervals obtained from the laser measurement system; $X_{m}$, mean of time intervals obtained from the laser measurement system.

The values obtained from the measuring systems were sent as digital data to the computer via a datalogger. The measuring system had an accuracy of 0.01 seconds.

\subsection{Statistical analysis}

This study was a factorial design consisting of three levels of cup, three levels of angular speed, two levels of variety, and two levels of seed size with three replications. As stated above, the coefficient of variation of seed spacing, percent value of doubles and skips were calculated. For each replication, the seed metering mechanism was rotated 10 times. The data was analyzed using analyses of variance (ANOVA) and comparison of means was made with Duncan's Multiple Range Test.

\section{Results and Discussion}

Table 3 shows the effects of the cups, angular speeds, varieties, and sizes on the values of $\mathrm{CV} \%$, percent value of doubles and skips. According to results of the ANOVA, the variety, the cup, the size and the angular speed, and two way interactions of cup $\mathrm{x}$ angular speed (C x A) had significant effect on the values of $\mathrm{CV} \%$. In addition, the cup, variety, size, and angular speed affected the percent value of doubles and skips. There were no significant interactions for the percent value of doubles and skips. On the other hand, as seen from Table 3, the interactions other than $\mathrm{C} \times \mathrm{A}$ were not significant, therefore they were not taken into considerations.

Table 3- Analysis of variance of cup, seed variety, seed size, and angular speed on values of CV\%, and the percent value of skips and doubles

Çizelge 3-\% CV, ikili atma ve boş bırakma üzerine kepçe, tohum çeşidi, tohum büyüklüğü ve açışal hızın varyans analizi

\begin{tabular}{|c|c|c|c|c|c|c|c|}
\hline \multirow[b]{2}{*}{ Variation sources } & \multicolumn{3}{|c|}{$C V, \%$} & \multicolumn{2}{|c|}{ Doubles, \% } & \multicolumn{2}{|c|}{ Skips, \% } \\
\hline & $D F$ & $M S$ & $P$ & $M S$ & $P$ & $M S$ & $P$ \\
\hline $\operatorname{Cup}(\mathrm{C})$ & 2 & 271.967 & $0.000^{[\mathrm{a}]}$ & 127.708 & $0.000^{[\mathrm{a}]}$ & 63.851 & $0.000^{[\mathrm{a}]}$ \\
\hline Variety (V) & 1 & 425.667 & $0.000^{[\mathrm{a}]}$ & 6.211 & $0.001^{[\mathrm{a}]}$ & 88.408 & $0.000^{[\mathrm{a}]}$ \\
\hline Size (S) & 1 & 141.587 & $0.000^{[\mathrm{a}]}$ & 323.837 & $0.000^{[\mathrm{a}]}$ & 15.177 & $0.000^{[\mathrm{a}]}$ \\
\hline Angular speed (A) & 2 & 718.372 & $0.000^{[\mathrm{a}]}$ & 4.980 & $0.000^{[\mathrm{a}]}$ & 9.354 & $0.000^{[\mathrm{a}]}$ \\
\hline Replication & 2 & 1.648 & 0.795 & 1.050 & 0.129 & 0.046 & 0.953 \\
\hline $\mathrm{C} \times \mathrm{V}$ & 2 & 10.517 & 0.238 & 0.141 & 0.754 & 0.203 & 0.810 \\
\hline $\mathrm{C} \times \mathrm{S}$ & 2 & 12.983 & 0.171 & 0.131 & 0.770 & 1.169 & 0.301 \\
\hline $\mathrm{C} \times \mathrm{A}$ & 4 & 30.141 & $0.004^{[\mathrm{a}]}$ & 0.366 & 0.572 & 0.667 & 0.597 \\
\hline $\mathrm{V} \times \mathrm{S}$ & 1 & 0.016 & 0.963 & 0.002 & 0.946 & 0.019 & 0.889 \\
\hline $\mathrm{V} \times \mathrm{A}$ & 2 & 10.276 & 0.245 & 0.298 & 0.553 & 0.042 & 0.957 \\
\hline $\mathrm{S} \times \mathrm{A}$ & 2 & 18.761 & 0.080 & 0.117 & 0.791 & 0.017 & 0.983 \\
\hline $\mathrm{C} \times \mathrm{V} \times \mathrm{S}$ & 2 & 6.899 & 0.387 & 0.719 & 0.243 & 0.351 & 0.694 \\
\hline$C \times V \times A$ & 4 & 2.638 & 0.831 & 0.049 & 0.983 & 0.012 & 1.000 \\
\hline $\mathrm{C} \times \mathrm{S} \times \mathrm{A}$ & 4 & 4.598 & 0.635 & 0.355 & 0.587 & 0.285 & 0.878 \\
\hline$V \times S \times A$ & 2 & 4.062 & 0.570 & 0.243 & 0.616 & 0.739 & 0.466 \\
\hline Error & 74 & 7.178 & & 0.499 & & 0.958 & \\
\hline Total & 107 & & & & & & \\
\hline
\end{tabular}

[a], significant at $1 \%$ level of probability; DF, degrees of freedom; MS, mean square 


\subsection{Effect of the cups on the seed spacing uniformity, doubles and skips}

The effect of cups on value of $\mathrm{CV} \%$, percent value of doubles and skips was statistically significant $(\mathrm{P}<0.01)$. The highest value of CV\% was determined as $29.24 \%$ for C1 (Table 4 ). The lowest value of CV\% was determined as $23.76 \%$ for $\mathrm{C} 2$. The small cup showed more variability of spacing than the big cup. So, it can be said that $\mathrm{C} 2$ for potato seeds in the range of 25 to 65 seed size would be appropriate. The doubles and skips were observed as the main source of deterioration of the seed spacing uniformity, the highest percent value of doubles was determined as $6.90 \%$ for $\mathrm{C} 3$. The lowest percent value of doubles was determined as $3.13 \%$ for $\mathrm{C} 1$. However, when looking at percent value of skips, the highest percent value of skips was determined as $5.07 \%$ for $\mathrm{C} 1$. There was no statistically significant difference between $\mathrm{C} 2$ and $\mathrm{C} 3$ for percent value of skips. As the highest percent value of doubles was $6.90 \%$ for C3, the highest percent value of skips was $5.07 \%$ for $\mathrm{C} 1$. It was shown that the effect of the skips was greater than that of doubles on value of $\mathrm{CV} \%$.

Table 4- Effects of cups, seed varieties, seed sizes and angular speeds on values of $\mathrm{CV} \%$, percent values of skips and doubles

Table 4-\% CV, ikili atma ve boş bırakma üzerine kepçe, tohum çeşidi, tohum büyüklüğ̈̈ ve açısal hızın etkisi

\begin{tabular}{|c|c|c|c|c|}
\hline Treatments & & $\begin{array}{c}C V \\
\% \\
\end{array}$ & $\begin{array}{c}\text { Doubles, } \\
\%\end{array}$ & $\begin{array}{c}\text { Skips, } \\
\% \\
\end{array}$ \\
\hline \multirow{4}{*}{ Cups } & $\mathrm{C} 1$ & $29.24 \mathrm{a}^{*}$ & $3.13 \mathrm{c}$ & $5.07 \mathrm{a}$ \\
\hline & $\mathrm{C} 2$ & $23.76 \mathrm{c}$ & $4.95 \mathrm{~b}$ & $2.94 \mathrm{~b}$ \\
\hline & $\mathrm{C} 3$ & $26.11 \mathrm{~b}$ & $6.90 \mathrm{a}$ & $2.62 \mathrm{~b}$ \\
\hline & LSD & 1.26 & 0.33 & 0.46 \\
\hline \multirow{2}{*}{ Potato varieties } & Agria & $24.39 \mathrm{~b}$ & $5.23 \mathrm{a}$ & $2.64 \mathrm{~b}$ \\
\hline & Marfona & $28.36 \mathrm{a}$ & $4.75 \mathrm{~b}$ & $4.45 \mathrm{a}$ \\
\hline \multirow{2}{*}{$\begin{array}{l}\text { Potato sizes, } \\
\mathrm{mm}\end{array}$} & $25-45$ & $27.52 \mathrm{a}$ & $6.73 \mathrm{a}$ & $3.17 \mathrm{~b}$ \\
\hline & $45-65$ & $25.23 \mathrm{~b}$ & $3.26 \mathrm{~b}$ & $3.92 \mathrm{a}$ \\
\hline \multirow{4}{*}{$\begin{array}{l}\text { Angular speeds, } \\
\mathrm{rad} \mathrm{s}^{-1}\end{array}$} & 0.9 & $22.83 \mathrm{c}$ & $5.35 \mathrm{a}$ & $3.06 \mathrm{~b}$ \\
\hline & 2.04 & $24.90 \mathrm{~b}$ & $5.02 \mathrm{a}$ & $3.51 \mathrm{~b}$ \\
\hline & 3.18 & $31.39 \mathrm{a}$ & $4.61 \mathrm{~b}$ & $4.08 \mathrm{a}$ \\
\hline & LSD & 1.26 & 0.33 & 0.46 \\
\hline
\end{tabular}

*, means in a single column without the same letter are significantly different at the $5 \%$ level using the LSD test

\subsection{Effect of potato shape on the seed spacing uniformity, doubles and skips}

The results of the effect of seed shape on value of $\mathrm{CV} \%$, percent value of doubles and skips are given in Table 4. The statistical results show that the seed shape affected the seed spacing uniformity, doubles and skips. The highest value of CV\% was determined as $28.36 \%$ for Marfona, while the lowest value of CV\% was determined as $24.39 \%$ for Agria. Oblong shaped Agria had less variability of seed spacing than spherical shape Marfona. Similarly, Buitenverf et al (2006) showed that the standard deviation of round balls was higher than oblong seeds. In contrast, Al-Gaadi \& Marey (2011) found that Hermes variety of potato with spherical shape indicated significantly lower value of CV\% than oblong shape Sponta variety of potato. The percent values of doubles were $5.23 \%$ and $4.75 \%$ for Agria and Marfona, respectively. The difference between Agria and Marfona was $0.48 \%$ for doubles. The percent values of skips were $2.64 \%$ and $4.45 \%$ for Agria and Marfona, respectively. The difference between Agria and Marfona was $1.81 \%$ for skips. Skips were the main source of disturbance of the seed spacing uniformity. It was observed in experiments that it was more difficult to keep spherical potato seeds on the cup than oblong potato seeds, because, the spherical potato seeds could fall down easier than oblong potato seeds. In addition, this showed that oblong seeds were clutched by holding pins better than spherical seed, and most probably, oblong seeds were grabbed by cups better than spherical seeds.

\subsection{Effect of potato size on the seed spacing uniformity, doubles and skips}

It was determined that seed size was an important parameter on the seed spacing uniformity. The results of values of $\mathrm{CV} \%$, and percent values of doubles and skips affected by seed size are shown in Table 4 . As the seed size increased, the seed spacing uniformity increased. The highest value of $\mathrm{CV} \%$ was determined as $27.52 \%$ for $25-45 \mathrm{~mm}$ seed size. The lowest value of $\mathrm{CV} \%$ was determined as $25.23 \%$ for $45-65 \mathrm{~mm}$ seed size. Misener (1982) found that as the seed size increased, the accuracy of seed spacing increased. The highest percent value of doubles was obtained from $25-45 \mathrm{~mm}$ seed size with $6.73 \%$. The lowest percent value of doubles was obtained from 45-65 $\mathrm{mm}$ seed size with $3.26 \%$. These results agree with 
the results reported by Al-Gaadi \& Marey (2011). They found that percent value of doubles were 5.35, 4.18 and $3.31 \%$ for $35-45,45-55$ and $55-65 \mathrm{~mm}$ seed size, respectively. As potato size increased, percent value of skips increased. The highest percent value of skips obtained from $45-65 \mathrm{~mm}$ seed size was $3.92 \%$. The lowest percent value of skips obtained from $25-45 \mathrm{~mm}$ seed size was $3.17 \%$. These results were supported by Al-Gaadi \& Marey (2011). They determined that percent value of skips had a range from 5.19 to $7.30 \%$. Misener (1982) compared the cup type and pick type potato planters in terms of various seed size. He showed that percent values of skips and doubles ranged from 3.8 to 9.2 and from 6.6 to 23.7, respectively. Misener (1982) and Altuntas et al (2004) determined that as the size of seed increased, the number of skips increased. In addition, they found that small seeds increased the number of doubles.

\subsection{Effect of angular speed on the seed spacing uniformity, doubles and skips}

The accuracy of the seed spacing uniformity tended to increase as the angular speed reduced. The value of $\mathrm{CV} \%$ ranged from 22.83 to $31.39 \%$ (Table 4). The highest value of $\mathrm{CV} \%$ was found as $31.39 \%$ for the angular speed of $3.18 \mathrm{rad} \mathrm{s}^{-1}$. The lowest value of $\mathrm{CV} \%$ was found as $22.83 \%$ for the angular speed of $0.9 \mathrm{rad} \mathrm{s}^{-1}$. The seed spacing uniformity was the best in lower angular speed as indicated by the seed spacing uniformity values. Research results of Misener (1979), Altuntas (2005) and Al-Gaadi \& Marey (2011) agree with these results. However, Buitenwerf et al (2006) and Sieczka et al (1986) stated that as the speed increased, the accuracy of seed spacing became better. Al-Gaadi \& Marey (2011) determined that the values of $\mathrm{CV} \%$ were $28.73,37.10$, and $54.53 \%$ for the ground speeds of $1.80,2.25$, and $3.00 \mathrm{~km} \mathrm{~h}^{-1}$, respectively. Entz \& LaCroix (1984), Sieczka et al (1986) and Misener (1982) stated that the coefficient of variation of seed spacing obtained from different potato planters ranged from $20 \%$ to $80 \%$. Misener (1979) stated that the values of CV\% for the pick type potato planter ranged from 55.3 to $68.7 \%$ while the values of $\mathrm{CV} \%$ for the cup type potato planter ranged from 59.2 to $87.1 \%$. The change of angular speed was significantly affected the percent value of doubles and skips. The highest percent value of doubles for the angular speed of $0.9 \mathrm{rad} \mathrm{s}^{-1}$ was determined as
$5.35 \%$. The lowest percent value of doubles for the angular speed of $3.18 \mathrm{rad} \mathrm{s}^{-1}$ was found as $4.61 \%$. As the angular speed increased, percent value of doubles decreased. The highest percent value of skips for the angular speed of $3.18 \mathrm{rad} \mathrm{s}^{-1}$ was determined as $4.08 \%$. The lowest percent value of skips for the angular speed of $0.9 \mathrm{rad} \mathrm{s}^{-1}$ was obtained as $3.06 \%$. Increase of the angular speed caused the percent value of skips to increase. Misener (1979) found that the pick type planter gave fewer doubles at the lower ground speeds. He also stated that, except two planters, all the other planters operating in the ground speed range of 5.6 to $7.2 \mathrm{~km} \mathrm{~h}^{-1}$ produced doubles more than skips. Al-Gaadi \& Marey (2011) determined that percent value of doubles and skips were 5.93, 4.62 and $2.29 \%$, and 3.91, 5.74 and $9.11 \%$ for the ground speed of $1.80,2.25$, and $3.00 \mathrm{~km} \mathrm{~h}^{-1}$, respectively. These results agree with our results. The effect of $\mathrm{C}$ x A interaction on CV\% was significant. Plot of this interaction is presented in Figure 8. From this figure, it can be seen that $\mathrm{CV} \%$ value of $\mathrm{C} 2$ was lower than those of the other cups for the angular speed of $0.9 \mathrm{rad} \mathrm{s}^{-1}$.

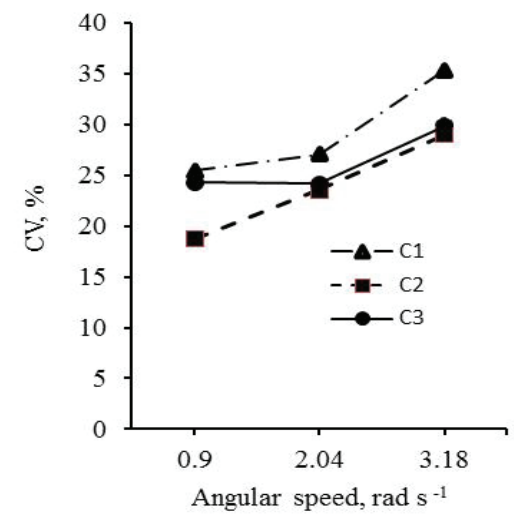

Figure 8- Plot of $\mathrm{C} x \mathrm{~A}$ interaction on $\mathrm{CV}$, \% value of angular speed

Şekil 8-Açısal hızın \% CV üzerine C x A interaksiyon grafiği

\section{Conclusions}

A full automatic potato planter with the seed metering mechanism with the vertical disc was tested at different cups, angular speeds, seed sizes 
and shapes in laboratory. The laboratory tests showed that the cup, the angular speed, potato sizes and potato shapes have significant effect on the seed metering mechanism. The best seed spacing uniformity was obtained from $\mathrm{C} 2$. Both small and large cups disturbed the seed spacing uniformity. As cup size increased, percent value of doubles increased, although percent value of skips decreased. The effects of seed shapes and seed sizes on the seed spacing uniformity, and percent values of doubles and skips were significant. The seed spacing uniformity of oblong potato seeds was better than that of spherical potato seeds. Skips value of oblong potato seeds was lower than that of spherical potato seeds. Nevertheless, the percent value of doubles obtained from oblong potato seeds was slightly higher than that of spherical potato seeds. Small potato seeds led to an increase in the value of $\mathrm{CV} \%$. The reason for this was the doubles. The angular speed influenced seed spacing uniformity significantly. Increasing the angular speed decreased the seed spacing uniformity. As the angular speed increased, percent value of doubles decreased and percent value of skips increased.

\section{Acknowledgements}

The author is grateful for financial support from the Research Fund of Atatürk University, Erzurum, Turkey, and for helps in the preparation and sending of cups from Kenan ERTUGRUL Tarım Makineleri, Özel Organize Sanayi Bölgesi, Nevsehir, Turkey.

\begin{tabular}{|ll|}
\hline \multicolumn{2}{|l|}{ Abbreviations and Symbols } \\
\hline$a, b, c$ & Dimensions of seed, $\mathrm{mm}$ \\
ANOVA & Analysis of variance \\
$\mathrm{CV}$ & Coefficient of variation, $\%$ \\
$D_{p}$ & Geometric mean diameter, mm \\
LDR & Light dependent resistor \\
$N$ & Total number of spacing \\
$N_{d}$ & Number of $\mathrm{t}_{\mathrm{d}}$ \\
$N_{s}$ & Number of $\mathrm{t}_{\mathrm{s}}$ \\
$S D$ & Standard deviation \\
$S_{p}$ & Sphericity, \% \\
$S_{f}$ & Shape factor, \% \\
$t, t_{d}, t_{s}$ & Time, s \\
$X_{m}$ & Mean of time intervals, $\mathrm{s}$ \\
\hline
\end{tabular}

\section{References}

Al-Gaadi K A \& Marey S A (2011). Effect of forward speed and tuber characteristics on tuber spacing uniformity for a cup-belt potato planter. Middle-East Journal of Scientific Research 8(4): 753-758

Altuntas E (2005). The effects of some operational parameters on potato planter's performance. Agricultural Mechanization in Asia, Africa, and Latin America 36(2): 71-74

Altuntas E, Taşer Ö F \& Tekelioğlu O (2004). Determination of the effects of the tuber size and different vibration positions of the planting unit on seed tuber distribution pattern with a full automatic potato planter. Tarim Bilimleri Dergisi-Journal of Agricultural Sciences 10(1): 104-110

Buitenwerf H, Hoogmoed W B, Lerink P \& Müller J (2006). Assessment of the behavior of potatoes in a cup-belt planter. Biosystems Engineering 95(1): 35-41

Bussan A J, Mitchell P D, Copas M E \& Drilias M J (2007). Evaluation of the effect of density on potato yield and tuber size distribution. Crop Sciences Society of America 47: 2462-2472

Boydas M G \& Uygan F (2012). Influence of seed physical properties and speed on the external mechanical damage index and in-row spacing uniformity in an automatic potato planter. Tarim Bilimleri DergisiJournal of Agricultural Sciences 18(2): 126-136

Creamer N G, Crozier C R \& Cubeta M A (1999). Influence of seed piece spacing and population on yield, internal quality, and economic performance of Atlantic, Superior, and Snowden potato varieties in Eastern North Carolina. American Journal of Potato Research 76: 257-261

Cross V S \& Ohms R E (1967). Better potato stands. Idaho Agricultural Extension Bulletin: No:486, Idaho, Moscow. Available at http://digital.lib.uidaho. edu/cdm/compoundobject/collection/ui_ep/id/19763/ rec/834 (Accessed date: 10 May 2015)

Culpin C (1992). Farm Machinery. $12^{\text {th }}$ Edition, Blackwell Scientific Publication, Oxford

Entz M H \& LaCroix L J (1984). The effect of in-row spacing and seed type on the yield and quality of a potato cultivar. American Potato Journal 61: 93-105

FAO (2015). FAOSTAT. Rome, Italy: United Nations FAO. Available at http://faostat.fao.org/site/567/ DesktopDefault.aspx?PageID=567\#ancor (Accessed date: 16 May 2015) 
Getachew T, Belew D \& Tulu S (2012). Yield and growth parameters of potato (Solanum tuberosum L.) as influenced by intra row spacing and time of earthing up: in Boneya Degem district, Central Highlands of Ethiopia. International Journals of Agricultural Research 7(5): 255-265

Güllüoglu L \& Arioglu H (2009). Effects of seed size and in-row spacing on growth and yield of early potato in a Mediterranean-type environment in Turkey. African Journal of Agricultural Research 4(5): 535-541

James W C, Lawrence C H \& Shih C S (1973). Yield losses due to missing plants in potato crops. American Potato Journal 50: 345-352

James W C, Bradley R H E, Smith C S \& Wong S T (1975). Misses in potato crops in New Brunswick in 1973; Their extent, distribution and cause. American Potato Journal 52(3): 83-87

Khairy M F (1997). Performance evaluation of potato planter in sandy soil. Misr Journal of Agricultural Engineering 14(1): 119-129

Klassen J (1974). Potato planter speeds-how do they affect stand and production. In: Proceedings of the $13^{\text {th }}$ Annual Washington State Potato Conference and Trade Fair, 29-31 January, Moses Lake, Washington, USA, pp. 71-74

Klassen J (1975). Planter performance study. In: Proceedings of the $14^{\text {th }}$ Annual Washington State Potato Conference and Trade Fair, 4-6 February, Moses Lake, Washington, USA, pp. 43-47

Love S L \& Thompson-Johns A (1999). Seed piece spacing influences yield, tuber size distribution, stem and tuber density, and net returns of three processing potato cultivars. HortScience 34: 629-633

Mathworks (2011). Matlab version 2011b. Mathworks Company

McPhee J E, Beattie B M, Corkrey R \& Fennell J F M (1996). Spacing uniformity-yield effects and in-field measurement. American Potato Journal 73: 167-171

Misener G C (1979). Relative performance of cup and pick type potato planters. Canadian Agricultural Engineering 21(2): 131-134

Misener G C (1982). Potato planters-uniformity of spacing. Transactions of the ASAE 25(6): 1504-1505

Mohsenin N N (1986). Physical Properties of Plant and Animal Materials. Gordon and Breach Science Publishers, New York. NY
Pavek M J \& Thornton R E (2003). Poor planter performance: What's it costing the average Washington potato grower? In: Proceedings of the $42^{\text {nd }}$ Annual Washington State Potato Conference and Trade Fair, 4-6 February, Moses Lake, Washington, USA, pp. 13-21

Potato (2015). The potato of cultivation. http://www. fao.org/potato-2008/en/potato/index.html (Accessed date: 02 February 2015)

Rex B L, Russell W A \& Wolfe H R (1987). The effect of spacing of seed pieces on yield, quality and economic value for processing of shepody potatoes in Manitoba. American Potato Journal 64: 177-189

Rupp J N \& Thornton RE(1992). Seed placement and plant stand-is it worth worrying about? Proceedings of the $31^{\text {st }}$ Annual Washington State Potato Conference and Trade Fair, 4-6 February, Moses Lake, Washington, USA. pp. 167-181

Schotzko R T, Hyde G M \& Thornton R E (1983). The dollars and cents of the 1982 potato seed size and spacing survey. In: Proceedings of the 22nd Annual Washington State Potato Conference and Trade Fair, 1-3 February, Moses Lake, Washington, USA, pp. 23-29

Seyedbagheri M (2006). On-farm evaluation of potato planter performance. Available at https://www. researchgate.net/publication/241015552_ON_ FARM_EVALUATION_OF_POTATO_PLANTER_ PERFORMANCE (Accessed date: 17 May 2015)

Sieczka J B, Ewing E E \& Markwardt E D (1986). Potato planter performance and effects of non-uniform spacing. American Potato Journal 63: 25-37

Steele D D, Bon T A \& Moos J A (2010). Capstone design experiences in the development of a two-row plot scale potato planter. Applied Engineering in Agriculture 26(1): 173-182

Taheri S \& Shamabadi Z (2013). Effect of planting date and plant density on potato yield, approach energy efficiency. International Journal of Agriculture and Crop Sciences 5(7): 747-754

Thornton R E, Schotzko T \& Hyde G (1983). Some other factors in obtaining good plant stands. In: Proceedings of the $22^{\text {nd }}$ Annual Washington State Potato Conference and Trade Fair, 1-3 February, Moses Lake, Washington, USA, pp. 93-101

Zoraki M \& Acar A I (2000). Optimum design of cup shape used in full automatic potato planter. Tarim Bilimleri Dergisi-Journal of Agricultural Sciences 6(4): $135-140$ 